\title{
AN UNUSUAL TYPE OF GROOVED STONE AXE
}

\section{By Charles R. Keyes ${ }^{1}$}

An Indian stone axe submitted to me for study and description by Curator E. R. Harlan of the State Historical Department of Iowa is so unusual a specimen that I believe it worthy of special notice. As the axe-maker's art reached a very high level of development in Iowa, it follows that any specimen which can be called extraordinary here is to be counted among the best productions of its kind known to American archaeology.

This particular axe was recently presented to the State Historical Department by Mr. Thomas E. De Hart of Van Buren County, having been found on his farm some two miles from Keosauqua about 1880, and having been in his continuous possession until given to the state. It is a beautiful specimen of diorite, finely polished throughout, the white feldspar crystals in the dark green hornblende producing that mottled appearance so characteristic of this tougher-than-granite igneous rock. Though by no means the largest of the Iowa axes, it is considerably larger than the average, being four inches wide, nine inches long, two and one-fourth inches thick and weighing six pounds and eleven ounces. The grooves run diagonally a little downward from the front to the back, a device which would incline the blade somewhat closer than the poll to the hand of the wielder and bring the cutting edge into the most effective position for a slashing downward blow. The poll is flattened and, being drawn in all around from the grooves and front and back, is nearly elliptical in form. The front and back are straight and parallel, except near the top of the poll, and are slightly hollowed, either to satisfy the

1 Charles Reuben Keyes is a $\mathrm{Ph}$. B., Cornell College, 1894, and an A. M. from Harvard, 1898; was principal of schools in Blairstown, Iowa, 1894-1897; instructor of German in University of California, 1900-1903; author of "Rime and Alliteration in Modern English and German Prose" and "The Omission of the Auxiliary Verb in German." He was a graduate student of Harvard, 1897-1900, and of the Universities of man." He was a graduate student of Harvard, $1897-1900$, and of the Universities of until present time; alumni yrofessor, 1912 to present time. He talks on archaeology and is a bird lover. Professor Keyes is naturally an archaeologist as that is his hobby in life. He has always been a natural student along this line and has done much personal investigating. 
taste of the maker or possibly to provide for wedging in case the handle needed to be tightened.

It is not, however, the beauty, size and fine workmanship of this axe that give it chief claim to special recognition. Many other Iowa axes are equally fine in material and workmanship.

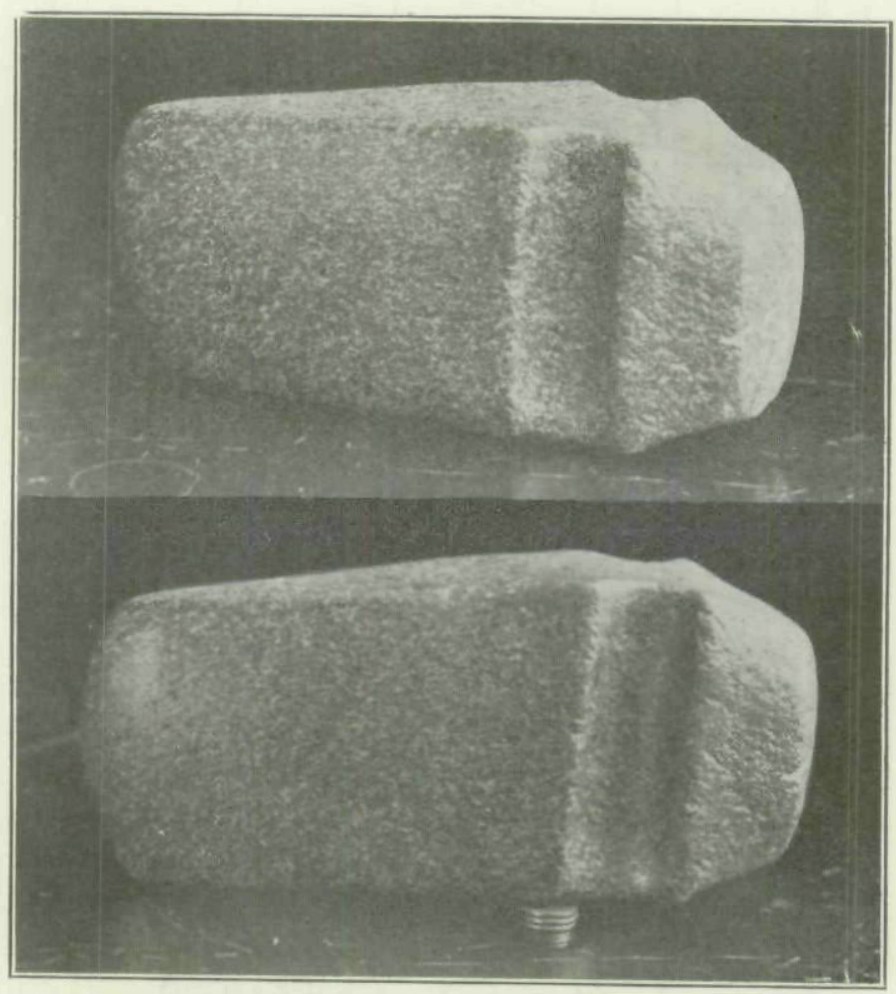

\section{GROOVED STONE AXE}

Found on the farm of Thomas E. DeHart, near Keosauqua, in 1880.

It is rather these qualities, combined with its unusual form. Most grooved axes, wherever found, are either grooved "all-round," the grooves entirely encircling the implement, or "three-fourths," that is, across both faces and across the front. This Van Buren County axe is grooved across the two broad faces only, the front 
being flattened quite like the back and showing no trace of a groove. It is, in short, the finest specimen known to me of the rare "Keokuk type" stone axe, a type first described by Fowke in 1896 on the basis of five specimens from near Keokuk, Iowa, in the collections of the Smithsonian Institution. The original reference is brief and is here quoted in full from an article entitled "Stone Art," by Gerard Fowke, Thirteenth Annual Report of the Bureau of American Ethnology for 1891-92 (published in 1896), page 68, under a classification of grooved stone axes in the Smithsonian collection: [Type] "G. grooved on faces only, with both sides flat (figure 38, of granite, from Keokuk, Iowa). There are from the same place one of porphyry, one of argillite, and three of sienite. This and the preceding form $[\mathrm{F}]$ seem peculiar to that locality."

Apparently these Keokuk-type axes have remained rare in collections and Mr. Fowke's name for the type, though a good one, has received no general recognition. Nevertheless, an axe grooved on the faces only is a very distinct type, possibly even farther removed from the two common types, the all-round and the threefourths grooved, than these two are from each other. The Keokuk axe even suggests a different method of hafting from that employed with the commoner types, a tough withe doubled around the groove and secured with cords or rawhide. An axe grooved on the faces only and with a flat or slightly hallowed front presents two sharp angles over which a withe thus bent would tend constantly to cut and break. The Keokuk axe suggests a hafting by means of two straight withes of equal length fitted into the grooves so as to project a little beyond the front and fastened together both at front and back. It is to be hoped that an axe of this type may be discovered sometime in its original handle, that the method of hafting may be definitely settled. Meanwhile it remains a distinct type, and its neglect in the literature is probably due to its comparative scarcity and to its restriction geographically to a rather limited area.

At present there are known to me a total of fifty-two axes of the Keokuk type, including the five mentioned by Fowke. Of this total a single specimen is from Wisconsin; one is from near 
McGregor, though doubt exists as to whether from the Wisconsin or the Iowa side of the river; two are from Illinois; two are from near Maquoketa, Iowa; all the others are Iowa specimens and, so far as definitely catalogued, are from the southeast quarter of the state. The collection of the State Historical Department of Iowa contains twenty-three specimens, the largest number, doubtless, to be found in any one place. The others are scattered in various collections, public and private.

It will be seen that the total amount of information concerning this unusual type of stone axe is meager and that further data is, therefore, very desirable. It is the hope of the writer that all who possess either specimen or information may be kind enough to furnish the data on the basis of which a definite account of the Keokuk axe may be written.

Mt. Vernon, Iowa, Nov. 15, 1920.

\section{THE LOTUS ISLANDS AT NAUVOO}

A late issue of the Chicago Inter-Ocean contains a sketchy and readable article from a correspondent at Nauvoo, giving an account of a visit to the islands between that city and Montrose, in search of the magnificent and fragrant lotus flower.

More than a third of a century ago, we have sought and found those gorgeous flowers, and the more common water lilies, on the same spot; though in our ignorance of natural history and things, we only knew them as yellow and white water lilies.

The rich flowers rise above the surface of the water on pipelike stems several feet long; while the broad, green leaves, measuring four or five feet in circumference, rest upon the surface of the water. They are generally found in the deep recesses of the Islands, in still water several feet in depth.

The writer states that plants from that locality have been procured by the commissioners to stock a pond in the New York Central Park.

-From Gregg's Dollar Monthly and Old-Settlers' Memorial, Vol. I, No. 5, September, 1873. 
Copyright of Annals of Iowa is the property of State of Iowa, by \& through the State Historical Society of Iowa and its content may not be copied or emailed to multiple sites or posted to a listserv without the copyright holder's express written permission. However, users may print, download, or email articles for individual use. 